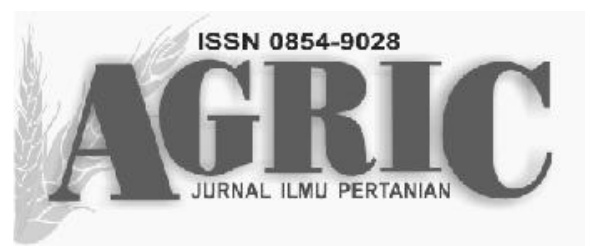

Fakultas Pertanian dan Bisnis Universitas Kristen Satya Wacana Jl. Diponegoro 52-60 SALATIGA 50711 - Telp. 0298-321212 ext 354 email: agric_fpb@yahoo.co.id, website: ejournal.uksw.edu/agric

\title{
DETEKSI CEMARAN BAKTERI KOLIFORM DAN Salmonella sp. PADA TEMPE YANG DIKEMAS DAUN PISANG DI DAERAH SALATIGA
}

\section{THE DETECTION OF COLIFORM AND Salmonella sp. CONTAMINATION ON THE BANANA LEAVES-WRAPPED TEMPEH IN SALATIGA AREA}

\author{
Khanifa Nurul Khaq \\ Mahasiswa Fakultas Biologi Universitas Kristen Satya Wacana \\ khanifa1995@gmail.com \\ Lusiawati Dewi \\ Fakultas Biologi Universitas Kristen Satya Wacana \\ lusisantoso@yahoo.com
}

\begin{abstract}
Banana leaves-wrapped tempeh is a traditional food as a conventional base of vegetable protein source. Fermented soybeans into tempeh assisted by fungi kind Rhizopusoligosporus, Rhizopusoryzae and Rhizopusstolonifer. Hygiene is very important in the process of fermentation as it will affect the end result of products. Packaging materials can serve as a protective product, but related to the materials used can be the sources of microbial contaminants in food packaging.For small-scale Tempeh industry in Salatiga area commonly use banana leaves to wrap tempeh.The absence of leaves-wrapped tempeh quality standard made the manufacturers ignore the tempeh processing standard quality. The purpose of this study is to obtain data on the number of coliforms contamination and the presence or absence of Salmonella sp. contamination on banana leaves-wrapped soybean tempeh from manufacturer of production $5-10 \mathrm{~kg}$ per day in District of Sidorejo and Tingkir, Salatiga with standar provision of SNI 3144-2015.For the detection of coliform contamination, method used Most probable Number (MPN) series of three tubes with Presumtive Test and Comfirmative Test, as well as the detection of Salmonella sp. with SSA (Salmonella Shigella Agar) specific media.

The research result that average sample of manufacturers in Sidorejo and Tingkir District have not met the standard limits of coliform contamination. The highest value of coliform contamination was $>1100 \mathrm{APM} / \mathrm{g}$ and lowest value was $7 \mathrm{APM} / \mathrm{g}$, while the Salmonella sp. detection in average yield positive result but found one sample showed negative result. Found one sample contaminated with Shigella sp. bacteria.High contamination of coliform and Salmonella was identified obtain from the tools and materials used in manufacturing process, lack of sanitation in manufacture environment, and so the individual as the manufacturer.
\end{abstract}

Keywords: leaves-wrapped tempeh,Coliforms, Salmonella sp. 


\section{PENDAHULUAN}

Tempe merupakan makanan sumber protein nabati yang dihasilkan dari proses fermentasi yang dibantu oleh kapang jenis Rhizopus oligosprorus, Rhizopus oryzae, dan Rhizopus stolonifer dengan kelembapan nisbi 70-80\% dan suhu lingkungan $30-36^{\circ} \mathrm{C}$. Higienitas sangat penting dalam proses fermentasi tempe karena akan mempengaruhi produk. Penggunaan bungkus tempe juga sangat berperan dalam menentukan mutu tempe. Bahan pembungkus dapat berfungsi sebagai pelindung produk, namun bahan pembungkus juga dapat menjadi sumber kontaminan mikrobia pada makanan yang di kemas (Nurita, 2009).

Untuk industri tempe skala kecil di daerah Salatiga, umumnya menggunakan daun pisang untuk mengemas tempe. Daun pisang sebagai bahan organik juga memiliki sifat yang perlu diperhatikan yaitu adanya kontaminan alami yang ada pada daun, sehingga ketika digunakan sebagai pengemas dapat mempengaruhi kualitas makanan yang dikemasnya. Dalam industri kecil pembuatan tempe daun biasanya tidak terlalu memperhatikan higienitas dari preparasi bahan baku, proses pembuatan, dan juga bahan untuk pembungkusnya. Sehingga diperlukan analisis pada beberapa industri kecil tempe kedelai bungkus daun di daerah kota Salatiga untuk memperoleh data mengenai cemaran koliform dan Salmonella sp.untuk dibandingkan dengan standar mutu yang telah ditetapkan pada SNI 3545:2015.

Tempe dengan kualitas baik memiliki ciri fisik ditutupi oleh hifa kapang, berwarna putih bersih yang merata pada permukaannya, memiliki struktur yang homogen dan kompak, serta berasa, berbau dan beraroma khas tempe. Melalui proses fermentasi, komponen nutrisi yang kompleks yang ada pada kedelai diubah oleh jamur tempe melalui proses metabolisme, sehingga dihasilkan senyawa-senyawa yang lebih sederhana (Dwinaningsih, 2010). Tempe merupakan produk berbasis kedelai yang memiliki manfaat, baik dari segi nutrisi maupun kesehatan. Sumber nutrisi yang terkandung dalam tempe antara lain 25\% protein, $5 \%$ lemak, 4\% karbohidrat, vitamin B12, dan kaya akan mineral. Dari beberapa penelitian menunjukkan bahwa nutrisi tempe lebih mudah dicerna, diserap, dan dimanfaatkan oleh tubuh dibandingkan dengan nutrisi kedelai yang dikonsumsi secara langsung (Dwinaningsih, 2010). Proses pembuatan tempe kedelai diawali dengan pensortiran kedelai, lalu kedelai dimasak dan direndam selama semalam lalu kedelai dicuci, dihilangkan kulit arinya, penirisan dan diberikan ragi tempe dengan perbandingan tertentu. Setelah itu dikemas dalam wadah plastik atau daun pisang dan dinkubasi untuk proses fermentasi.

Tempe adalah satu contoh produk makanan yang mudah mengalami kerusakan atau pembusukan. Tempe memiliki daya tahan penyimpanan hanya sekitar 2-3 hari, dimana apabila disimpan lebih dari itu tempe akan rusak atau tidak layak dimakan. Menurut Standar Nasional Indonesia (SNI) 3144:2015, tujuan dibuatnya standarisasi pada produk tempe adalah untuk menjaga kesehatan konsumen; menjamin perdagangan pangan yang jujur dan bertanggung jawab; pengembangan produk yang berkualitas; dan mendukung perkembangan industri tempe kedelai. Selain itu, dibuatkannya standar untuk tempe akan meningkatkan mutu tempe sebagai makanan tradisional. Berikut adalah standar mutu tempe kedelai berdasarkan SNI 3144-2015 (Anonim, 2015):

Penggunaan daun pisang untuk pembungkus tempe merupakan cara tradisional yang paling banyak dilakukan oleh produsen-produsen skala kecil di daerah Salatiga. Pembungkusan tempe dengan daun sama halnya dengan menyimpannya dalam ruang gelap dikarenakan sifat daun yang 
tidak tembus pandang, hal ini menjadi salah satu syarat ruang fermentasi yang baik. Dengan pembungkus daun, sirkulasi udara tetap dapat berlangsung melalui celah-celah lipatan daun (Suprapti, 2003). Daun pisang memiliki kelebihan pembungkus alami yang tidak mengandung bahan kimia, mudah ditemukan, mudah di lipat dan memberi aroma sedap. Pemakaian daun memiliki kekurangan, antara lain mudah sobek dan kebersihan kurang dikarenakan untuk membersihkannya hanya di lap pada permukaannya saja (Nurita, 2009).

Macam bakteri yang sering ada pada permukaan daun adalah Bacillus cereus, B.Subtilis, Lactobacillus acidophilussp., Staphylococcus aureus, S.epidermidis, Pseudomonas sp., Corynebacterium sp.,Micrococcus $s p$. Penggunaan pembungkus dalam fermentasi akan mempengaruhi cita rasa tempe kedelai yang dihasilkan. Selain karena faktor lingkungan dan pembungkus, juga karena adanya kemungkinan adanya reaksi yang terjadi antara bahan yang akan difermentasi dari komponen kemasan. Pengemasan pada tempe daun memiliki peranan penting dalam pengendalian dari kontaminasi mikroorganisme terhadap produk tempe yang dihasilkan. Produk tempe yang terkontaminasi oleh mikroorganisme patogen jika disimpan dalam kondisi yang cocok untuk aktivitas metabolisme dapat menimbulkan kerusakan produk tempe yang menimbulkan kebusukan dan membahayakan kesehatan konsumennya (Supardi dan Sukamto,1999).

Koliform dan Salmonella sp. sering dijadikan standar utama kebersihan pangan di industri. Hal ini dikarenakan dalam jumlah berlebih kedua bakteri ini dapat menurunkan kualitas produk pangan dan membahayakan konsumen dikarenakan akan menimbulkan penyakit khususnya pencernaan. Adanya keberadaan koliform dan Salmonella sp. menunjukkan bahwa kurangnya tingkat kebersihan dan keamanan pangan,sehingga ada kontaminasi dalam bahan atau proses produksi (Sukardi dkk., 2008). Koliform adalah kelompok bakteri sebagai indikator untuk mengetahui pencemaran bakteri patogen pada suatu sumber air. Kelompok bakteri yang disebut koliform antara lain Eschericia coli, Enterrobacter aerogenes, dan Citrobacter fruendii, Shigella $s p$. yang menjadi penyebab penyakit diare (Antara dkk., 2008).

Salmonella sp. adalah kelompok bakteri Gram negatif berbentuk batang dan tidak berspora. Bakteri ini ditemukan pada tahun 1880 pada penderita demam tifoid oleh Eberth dan dibenarkan oleh Robert Koch dalam budidaya bakteri pada tahun 1881. Bakteri ini memiliki sifat parasit yang menyebabkan reaksi peradangan tractus intestinal pada manusia dan hewan. Salmonella digolongkan dalam bakteri patogenik yang menjadi penyebab foodborne disease yang disebut Salmonellosis (Karsinah, 2004). Di laboratorium, Salmonella dapat tumbuh pada suhu $5-47^{\circ} \mathrm{C}$ dan optimum pada suhu $35-37^{\circ} \mathrm{C}$. $\mathrm{pH}$ pertumbuhan sekitar 4,0-9,0 dengan $\mathrm{pH}$ optimum $6,5-7,5$.

penelitian ini dilakukan untuk mendapatkan data jumlah cemaran koliform dan ada atau tidaknya cemaran Salmonella sp. pada tempe kedelai kemasan daun pisang dari produsen berskala produksi $5-10 \mathrm{~kg} / \mathrm{hari}$ di Kecamatan Sidorejo dan Tingkir, Kota Salatiga dengan standar ketentuan SNI 3144:2015.

\section{METODE PENELITIAN}

\section{Waktu Penelitian}

Penelitian ini dilakukan pada bulan SeptemberOktober 2016 bertempat di Laboratorium Mikrobiologi, Fakultas Biologi, Universitas Kristen Satya Wacana, Salatiga.

\section{Alat dan Bahan Penelitian}

Alat-alat yang digunakan dalam melakukan 
penelitian diantaranya adalah cawan petri, bunsen, gelas beaker $100 \mathrm{ml}$, gelas ukur 100 $\mathrm{ml}$, erlenmeyer $500 \mathrm{ml}$, tabung durham, pipet mikro P1000, pipet mikro P200. Untuk bahanbahan yang digunakan pada penelitian ini berupa tempe berkemasan daun pisang dari produsen di Kecamatan Sidorejo dan Tingkir, $\mathrm{NaCl}$ 0,85\%, akuades, medium Lactose Broth (LB), Brilliant Green Lactose Bile Broth 2\% (BGLB 2\%), dan Salmonella Shigella Agar (SSA).

\section{Pengambilan Sampel}

Sampel berasal dari total $35 \%$ pengrajin tempe berkemasan daun pisang berskala produksi 510kg/hari di Kecamatan Sidorejo dan Kecamatan Tingkir, Kota Salatiga. Enam sampel yang diambil, dipilih secara acak hingga memenuhi kuota sampel yang diperlukan dan mewakili tiap kecamatan.

Sampel A: produsen Tempe Daerah Macanan (Kec. Sidorejo)

Sampel B: produsen Tempe Daerah Tingkir Lor (Kec.Tingkir)

Sampel C: produsen Tempe Daerah KarangLo (Kec. Sidorejo)

Sampel D: produsen Tempe Daerah Gunungsari (Kec. Tingkir)

Sampel E: produsen Tempe Daerah Blotongan (Kec. Sidorejo)

Sampel F: produsen Tempe Daerah Kalibening (Kec. Tingkir)

\section{Preparasi dan Pengenceran}

Sampel uji dibuat 6 seri pengenceran, yaitu: $10^{-}$ ${ }^{1}, 10^{-2}, 10^{-3}, 10^{-4}, 10^{-5}$, dan $10^{-6}$. Pengenceran awal, sampel dilakukan dengan mencampurkan $25 \mathrm{~g}$ sampel tempe yang telah dihancurkan ke dalam $225 \mathrm{ml} \mathrm{NaCl} \mathrm{0,85 \%} \mathrm{dan} \mathrm{dihomogenkan}$ (pengenceran $10^{-1}$ ). Kemudian dalam mendapatkan pengenceran $10^{-2}$, suspensi awal diambil sebanyak $1 \mathrm{ml}$ lalu dimasukkan ke dalam tabung reaksi berisi $9 \mathrm{ml} \mathrm{NaCl} \mathrm{0,85 \%} \mathrm{dan} \mathrm{dihomogenkan.}$ Demikian dengan pengenceran $10^{-3}$, suspensi diambil sebanyak $1 \mathrm{ml}$ dari pengenceran $10^{-2}$, lalu dimasukkan ke dalam tabung reaksi berisi 9 $\mathrm{ml} \mathrm{NaCl} 0,85 \%$ dan dihomogenkan. Setelah itu, dari pengenceran $10^{-3}$ diambil sebanyak $1 \mathrm{ml}$, lalu dimasukkan ke dalam tabung reaksi pengenceran $10^{-4}$ berisi $9 \mathrm{ml} \mathrm{NaCl} 0,85 \%$. Pengenceran $10^{-4}$ diambil sebanyak $1 \mathrm{ml}$, lalu dimasukkan ke dalam tabung reaksi pengenceran $10^{-5}$ berisi $9 \mathrm{ml} \mathrm{NaCl} 0,85 \%$. Untuk mendapatkan pengenceran $10^{-6}$, pengenceran $10^{-5}$ diambil $1 \mathrm{ml}$ dan di masukkan ke dalam tabung pengenceran $10^{-6}$ berisi $9 \mathrm{ml} \mathrm{NaCl} \mathrm{0,85 \%} \mathrm{(Kartika} \mathrm{dkk,} \mathrm{2014).}$

\section{Pengujian Bakteri Koliform}

\section{Uji Dugaan (Presumtive Test)}

Masing-masing suspensi dari pengenceran $10^{4}, 10^{-5}$, dan $10^{-6}$ diambil sebanyak $1 \mathrm{ml}$ dan dimasukkan ke dalam 3 tabung berisi $9 \mathrm{ml}$ Lactose Broth dengan tabung durham terbalik. Suspensi sampel pengenceran $10^{-4}$ dimasukkan ke dalam 3 seri pertama tabung reaksi berisi $9 \mathrm{ml}$ Lactose Broth sebanyak masing-masing $1 \mathrm{ml}$. Selanjutnya suspensi sampel pengenceran $10^{-5}$ diambil sebanyak masing-masing $1 \mathrm{ml}$, dan dimasukkan ke dalam 3 seri kedua tabung reaksi berisi $9 \mathrm{ml}$ Lactose Broth. Terakhir suspensi sampel pengenceran $10^{-6}$ diambil sebanyak masingmasing $1 \mathrm{ml}$, dan dimasukkan ke dalam 3 seri ketiga tabung reaksi berisi $9 \mathrm{ml}$ Lactose Broth. Seluruh tabung diinkubasikan pada suhu $37^{\circ} \mathrm{C}$ selama 24-48 jam dan setelahnya dicatat jumlah tabung yang membentuk gas pada masing-masing pengenceran (Kartika dkk, 2014).

\section{Uji Penegasan (Confirmative Test)}

Tabung dari uji dugaan yang positif (terbentuk gas) secara hati-hati dikocok dengan vortex. Kemudian setiap tabung tersebut diambil 1 ose, dan dipindahkan ke tabung reaksi yang berisi 10 ml media Brilliant Green Lactose bile Broth 
$2 \%$ yang didalamnya terdapat tabung durham terbalik. Kemudian semua tabung diinkubasi pada suhu $37^{\circ} \mathrm{C}$ selama $24-48$ jam. Uji dinyatakan positif jika terbentuk gas dalam tabung durham. Pembentukan gas pada tiap tabung pengenceran dicatat jumlahnya, kemudian kombinasi tabung positif disesuaikan dengan tabel MPN (FDA BAM Appendix 2, 2001) dan dinyatakan dalam satuan APM/g.

\section{Deteksi Bakteri Salmonella sp.}

Larutan suspensi pengenceran $10^{-4}, 10^{-5}$, dan $10^{-6}$ masing-masing diambil sebanyak 0,2 $\mathrm{ml}$. Kemudian, larutan suspensi tersebut ditaburkan pada permukaan medium spesifik Salmonella Shigella Agar (SSA) dan diratakan menggunakan batang $\mathrm{L}$ steril. Tiap seri pengenceran dibuat 3 kali ulangan. Setelah semua seri pengenceran diinokulasikan, medium SSA diinkubasi pada suhu $37^{\circ} \mathrm{C}$ selama $24-48$ jam. Deteksi cemaran bakteri Salmonella sp. dilihat dari ada (+) atau tidak ada (-) pertumbuhan bakteri tersebut. Jika tumbuh koloni Salmonella $s p$., koloni tersebut tidak akan berwarna (colorless) dengan inti hitam besar di tengah (Narumi dkk, 2009).

\section{Analisis Data}

Data yang diperoleh dianalisis secara deskriptif dengan perlakuan 6 sampel dan ulangan tiga kali. Data yang sudah diolah kemudian dinilai kuantitas bakteriologis coliform dan kualitas ada atau tidaknya Salmonella sp.

\section{HASIL DAN PEMBAHASAN}

\section{Uji Koliform pada Tempe yang Dibungkus} Daun Pisang

Pada proses pembuatan tempe kedelai diperlukan suatu standar cemaran bakteri yang ditetapkan untuk menjaga kualitas tempe. Para produsen tempe perlu menyesuaikan standar produk Tempe Kedelai dalam standar SNI 31442015 yang telah ditetapkan seperti Tabel 1.

Tabel 1 Standar Mutu Tempe Kedelai Berdasarkan SNI 3144-2015

\begin{tabular}{|c|c|c|}
\hline Kriteria Uji & Satuan & Persyaratan \\
\hline \multicolumn{3}{|l|}{ Keadaan } \\
\hline Tekstur & - & $\begin{array}{l}\text { Kompak, jika diiris tetap utuh } \\
\text { (tidak mudah rontok) }\end{array}$ \\
\hline Warna & - & $\begin{array}{c}\text { Putih merata pada seluruh } \\
\text { permukaan }\end{array}$ \\
\hline Bau & - & $\begin{array}{c}\text { Bau khas tempe tanpa adanya } \\
\text { bau amoniak }\end{array}$ \\
\hline Kadar air (b/b) & fraksi massa, $\%$ & maks. 65 \\
\hline Kadar lemak (b/b) & fraksi massa, $\%$ & $\min .7$ \\
\hline Kadar Protein $(\mathrm{N} \times 5,71)(\mathrm{b} / \mathrm{b})$ & fraksi massa, \% & $\min .15$ \\
\hline Kadar serat kasar (b/b) & fraksi massa, \% & maks. 2,5 \\
\hline \multicolumn{3}{|l|}{ Cemaran logam } \\
\hline Kadmium (Cd) & $\mathrm{mg} / \mathrm{kg}$ & maks. 0,2 \\
\hline Timbal $(\mathrm{Pb})$ & $\mathrm{mg} / \mathrm{kg}$ & maks. 0,25 \\
\hline Timah (Sn) & $\mathrm{mg} / \mathrm{kg}$ & maks. 40 \\
\hline Merkuri (Hg) & $\mathrm{mg} / \mathrm{kg}$ & maks. 0,03 \\
\hline Cemaran arsen (As) & $\mathrm{mg} / \mathrm{kg}$ & maks. 0,25 \\
\hline \multicolumn{3}{|l|}{ Cemaran mikroba } \\
\hline Bakteri coliform & $\mathrm{APM} / \mathrm{g}$ & maks. 10 \\
\hline Salmonella sp. & - & negatif/25 g \\
\hline
\end{tabular}


Untuk hasil Uji Most Probable Number (MPN) dengan uji Dugaan dan uji Penegasan seri tiga tabung akan dibandingkan dengan batas baku cemaran koliform SNI 3122-2015. Hasil menunjukkan bahwa untuk sampel A, B, C, D, dan F belum memenuhi standar dikarenakan untuk batas baku cemaran koliform maksimal 10 APM/g, sedangkan sampel E sudah memenuhi standar yakni dengan hasil MPN 7 APM/g. Untuk hasil yang lebih jelas dapat dilihat pada Tabel 2.

Dari penelitian sebelumnya (Rizky, 2016) dilakukan anilisis deteksi cemaran koliform dan Salmonella sp.dengan sampel tempe bungkus plastik. Data Uji Most Probable Number (MPN) yang diperoleh digunakan sebagai kontrol atau pembanding untuk Uji MPN pada sampel tempe yang dikemas daun pisang. Untuk lebih jelasnya dapat dilihat pada Tabel 3.
Dari keenam sampel tempe yang diuji hanya sampel E yang menunjukan hasil negatif. Hal ini menandakan bahwa sampel tempe dari produsen ini aman dikonsumsi dan higienis. Pada sampel A, B, C, D, dan F menunjukan hasil positif adanya Salmonella sp. Untuk data cemaran Salmonella sp. paling banyak ditunjukkan pada pengenceran $10^{-4}$ sampel A dimana ditemukan ada 12 koloniSalmonella sp. Kontaminan Salmonella sp. bisa disebabkan dari daun sebagai pembungkus selain itu juga bisa disebabkan karena kurang maksimalnya proses perendaman biji kedelai, selama proses perendaman biji kedelai akan mengalami penurunan $\mathrm{pH}$ menjadi asam (5 sampai 4) karena proses fermentasioleh bakteri asam laktat. Bakteri kontaminan seperti Salmonella sp. tidak dapat tumbuh dengan nilai $\mathrm{pH}$ yang asam. Namun jika $\mathrm{pH}$ tidak dapat mencapai asam

Tabel 2 Hasil Uji Most Probable Number (MPN)/Angka Paling Mungkin (APM) Koliform Seri Tiga Tabung Pada Tempe yang Dikemas Daun Pisang

\begin{tabular}{ccllll}
\hline \multirow{2}{*}{ No } & Sampel & Uji Dugaan & Uji penegasan & $\begin{array}{l}\text { Hasil MPN } \\
\text { Koliform } \\
\text { (APM/g) }\end{array}$ & Keterangan \\
\cline { 3 - 4 } & $\begin{array}{l}\text { Kombinasi hasil } \\
\text { positif (LB) }\end{array}$ & $\begin{array}{l}\text { Kombinasi hasil } \\
\text { positif (BGLB) }\end{array}$ & (3-3-3 & $>1100$ & BMS \\
\hline 1 & A & $3-3-3$ & $3-3-3$ & $>1100$ & BMS \\
2 & B & $3-3-3$ & $3-3-2$ & 1100 & BMS \\
3 & C & $3-3-2$ & $3-2-2$ & 210 & BMS \\
4 & D & $3-2-2$ & $1-0-0$ & 7 & MS \\
5 & E & $1-0-0$ & $3-3-3$ & $>1100$ & BMS \\
6 & F & $3-3-3$ & \multicolumn{3}{l}{ MS $=$ Memenuhi Standar }
\end{tabular}

Tabel 3 Hasil Uji Most Probable Number(MPN)/Angka Paling Mungkin (APM) Coliform Sampel Tempe Kedelai Bungkus Plastik Seri Tiga Tabung Setelah 48 jam inkubasi

\begin{tabular}{|c|c|c|c|c|c|}
\hline \multirow[b]{2}{*}{ No } & \multirow[b]{2}{*}{ Sampel } & \multirow{2}{*}{$\begin{array}{c}\text { Uji Dugaan } \\
\text { Kombinasi Tabung } \\
\text { Positif Coliform } \\
\text { LB }\end{array}$} & \multicolumn{2}{|c|}{ Uji Penegasan } & \multirow[b]{2}{*}{ Keterangan } \\
\hline & & & $\begin{array}{c}\text { Kombinasi } \\
\text { Tabung Positif } \\
\text { Coliform BGLB } \\
2 \%\end{array}$ & $\begin{array}{c}\text { Hasil MPN } \\
\text { Coliform } \\
\text { (APM/g) }\end{array}$ & \\
\hline 1 & $\mathrm{~A}$ & $3-2-2$ & $3-2-2$ & 210 & BMS \\
\hline 2 & $\mathrm{~B}$ & $3-3-2$ & $3-3-2$ & 1.100 & BMS \\
\hline 3 & $\mathrm{C}$ & $3-2-2$ & $3-2-2$ & 210 & BMS \\
\hline 4 & $\mathrm{D}$ & $3-1-2$ & $3-1-2$ & 120 & BMS \\
\hline 5 & $\mathrm{E}$ & $2-3-1$ & $2-3-1$ & 36 & BMS \\
\hline 6 & $\mathrm{~F}$ & $3-1-1$ & $3-1-1$ & 75 & BMS \\
\hline
\end{tabular}


karena kurang lamanya proses perendaman, akan menyebabkan kontaminan tumbuh.

Untuk sampel C terdeteksi tidak hanya Salmonella $s p$. namun juga beberapa koloni Shigella $s p$. yang sangat mendominasi di media SSA. Di pengenceran $10^{-4}$ ditemukan hanya 2 koloni Salmonella sp. dan didominasi koloni Shigella $s p$. Terdeteksinya kedua bakteri ini menandakan bahwa tempe tidak aman dikonsumsi dan sanitasi lingkungan produsen tidak layak. Bakteri Shigella $s p$. ini dapat menyebabkan penyakit disentri basiler dan menghasilkan respon inflamasi pada kolon melalui enterotoksin dan invasi bakteri. Bakteri Shigella sp. dapat ditularkan melalui air dikarenakan tempat produksi yang dekat dengan saluran pembuangan air dan juga lalat yang memungkinkan hinggap di biji kedelai sebelum proses peragian. Selain itu juga ada beberapa faktor lain seperti sanitasi pekerja dan tempat penginkubasian tempe juga berpengaruh akan terdeteksinya bakteri patogenik Salmonella sp.pada tempe yang dibungkus daun. Rata-rata dari semua pekerja produsen tempe di Kecamatan Sidorejo dan Tingkir masih kurang memperhatikan sanitasi pada saat memproduksi tempe. Seperti halnya mencuci tangan tanpa memakai sabun sebelum bekerja, tidak memakai alat pelindung seperti masker, dan memakai alat produksi yang dibersihkan sekedarnya (Narumi, 2009).
Sanitasi pekerja yang kurang dan lingkungan yang kotor akan mempengaruhi kualitas tempe yang dihasilkan. Dalam survei, sebagian besar produsen untuk proses peragian biji kedelai sebelum pembungkusan daun dilakukan dengan tangan kosong tanpa memakai pelindung seperti kaos tangan. Hal ini menyebabkan kontaminasi produk tempe karena kontak langsung dengan perantara tangan pekerja yang kurang higienis (Wowon, 2003). Tempat inkubasi tempe dari produsen A dan B menggunakan papan kayu yang diberikan alas karung-karung dan diberi penutup berbahan terpal. Alas karung dan penutup terpal ini jarang diganti ataupun dibersihkan, sehingga akan memungkinkan tingginya kontaminasi oleh bakteri koliform ataupun Salmonella sp. karena kondisi yang semakin kotor. Dari segi tempat produksi ratarata produsen tempe di Kecamatan Tingkir untuk proses pemasakan dan pengemasan dilakukan di tempat dapur yang sangat dekat dengan kamar mandi. Jika suatu saat pekerja keluar dari toilet belum tentu mencuci tangan dengan sabun untuk bekerja kembali di area produksi. Selain itu juga kondisi tempat produksi yang kumuh dan terlalu terbuka memperbesar kontaminasi lewat udara. Lantai di area produksi pada produsen A, B, C, dan F masih berlantaikan tanah ataupun plesteran semen. Dalam kondisi lembab, lantai seperti ini menjadi tempat yang cocok untuk berkembangnya bakteri patogenik yang dapat

Tabel 4 Deteksi Salmonella sp. pada media SSA dengan Sampel Tempe Bungkus Daun Pisang

\begin{tabular}{|c|c|c|c|c|c|c|c|c|c|}
\hline \multirow{3}{*}{$\begin{array}{c}\text { Sampel } \\
\text { A }\end{array}$} & \multicolumn{9}{|c|}{ Pengenceran } \\
\hline & \multicolumn{3}{|c|}{$10-4$} & \multicolumn{3}{|c|}{$10-5$} & \multicolumn{3}{|c|}{$10-6$} \\
\hline & + & + & + & + & + & + & - & + & + \\
\hline B & + & - & + & + & + & - & + & - & - \\
\hline $\mathrm{C}$ & + & + & - & - & + & - & - & - & - \\
\hline $\mathrm{D}$ & + & + & + & + & + & - & - & + & + \\
\hline $\mathrm{E}$ & - & - & - & - & - & - & - & - & - \\
\hline $\mathrm{F}$ & + & + & + & + & + & + & + & + & + \\
\hline
\end{tabular}


menurunkan mutu tempe bungkus daun pisang (Karsinah, 2004).

\section{KESIMPULAN}

Lima sampel tempe (A,B,C,D, dan F) yang dikemas daun pisang yang ada di Kecamatan Sidorejo dan Kecamatan Tingkir, Kota Salatiga dinyatakan belum memenuhi standar. Lima sampel tersebutmempunyai nilai MPN cemaran koliform melebihi ambang batas dari standar SNI 3144-2015. Hanya sampel E yang memenuhi standar SNI 3144-2015.

\section{DAFTAR PUSTAKA}

Anonim. 2015. Tempe Kedelai. SNI 3144:2015.

Antara, dkk. 2008. Tingkat Cemaran Bakteri Coliform, Salmonella sp., dan Staphylococcus aureus Pada Daging Babi. Jurnal Agrotekno, Volume 14, 2: 51-55.

Astuti, N.P. 2009. Sifat Organoleptik Tempe Kedelai yang Dibungkus Plastik, daun Pisang, dan daun Jati. Universitas Muhammadiyah Surakarta,Solo.

Dwiningsih, E.A. 2010. Karakterisasi Kimia dan Sensori pada Tempe dengan Variasi Bahan Baku Kedelai/Beras dan Penambahan Angkak Serta Variasi Lama Fermentasi. http://eprints.uns.ac.id/210/1/ 170422411201010311.pdf

Ismail, D. 2012. Uji Bakteri Escherichia coli Pada Minuman Susu Kedelai Bermerek dan Tanpa Merek Di Kota Surakarta. Universitas Muhammadiyah Surakarta. Solo.

Kartika, Emma, Siti Khotimah, Ari Hepi Yanti. 2014. Deteksi Bakteri Indikator Keamanan Pangan Pada Sosis Daging Ayam Di Pasar Flamboyan Pontianak. Probiont, Volume 3, 2: 111-119.

Karsinah. 2004. Deteksi Salmonella. Universitas Airlangga. Surabaya.
Kusuma, R.D. 2016. Deteksi Cemaran Coliform dan Salmonella sp. pada Tempe Kedelai di Kecamatan Sidorejo dan Tingkir, Kota Salatiga. (https://publikasiilmiah.ums. ac.id/ bitstream/handle/11617/7927/58.pdf)

Narumi, dkk. 2009. Deteksi Pencemaran Bakteri Salmonella sp. Pada Udang Putih (Panaeus merguiensis) Segar Di Pasar Tradisional Kotamadya Surabaya. Jurnal Ilmiah Perikanan dan Kelautan, Volume 1, 1: 87-91.

Santoso, E. 2008. Bakteri asam laktat (BAL) pada cumi-cumi kering asin dan aktivitas penghambatannya terhadap bakteri patogen dan bakteri pembusuk. Agroteksos, 18: 46-53.

Sudarmadji, S., dkk. 2007. Prosedur Analisa untuk Bahan Makanan dan Pertanian. Liberty. Yogyakarta.

Sukardi, dkk. 2008. Uji Coba Penggunaan Inokulum Tempe Dari Kapang Rhizopus oryzae Dengan Subtrat Tepung Beras dan Ubikayu Pada Unit Produksi Tempe Sanan Kodya Malang. Jurnal Teknologi Pertanian, Volume 9, 8: 207-215.

Supardi dan Sukamto. 1999. Mikrobiologi, Pengolahan dan Keamanan Pangan. Alumni. Jakarta.

Widowati S, Yaniar, MEChristina dan R Holinesti. 2004. Analisis kerusakan produk tempe kedelai. Thesis. IPB. Bogor.

Winanti, R., dkk. 2014. Studi Observasi Higienitas Produk Tempe Berdasarkan Perbedaan Metode Inokulasi. Jurnal Ilmiah UNNES, Volume 1, 1: 39-46.

Wowon, dkk. 2003. Sanitasi Pekerja pada Penampungan Susu di KPSBU Lembang. http://pustaka.unpad.ac.id/wp-content/ uploads/2009/03/sanitasi_pekerja.pdf. 